\title{
The Persistence Existence of Gossip in Social Media and Exchange Days to Determine Stock Return in the Indonesia Stock Exchange
}

\author{
Sawidji Widoatmodjo \\ \{sawidjiw@pps.untar.ac.id\}, Universitas Tarumanagara, Jakarta, Indonesia.
}

\author{
Djabir Hamzah \\ \{djabirh@gmail.com\}, Faculty of Economics and Business,Hasanuddin University, Makassar, Indonesia.
}

\section{Indrianty Sudirman}

\{Indrianty_sudirman@yahoo.com\}, Faculty of Economics and Business,Hasanuddin University, Makassar, Indonesia.

\section{Ria Mardiana}

\{riamard67@gmail.com\}, Faculty of Economics and Business,Hasanuddin University, Makassar, Indonesia.

\begin{abstract}
It isn't easy to define whether a stock return is determined by a certain factor or exchange day. There were many researches that proved that some influenced stock returns. There were also many researches gave facts that stock returns were caused by specific exchange days, such as week day effect. This research tries to track this logic. We tested the impact of gossips - thatspread out through social media - tostock return and persistence of theimpact. To anticipate the impact of exchange days, this research also included them as control variables. Multivariate statistic technique and combined with event study were used as analysis technique. The result suggests that the gossips in social media don't show significance to influence the stock return, and no persistence to exist. The conclusion is that gossips in social media can't be used to determine stock returns.
\end{abstract}

Keywords:

gossip, stock return, social media, exchange day

Article Received: 18 October 2020, Revised: 3 November 2020, Accepted: 24 December 2020

\section{Introduction}

Gossips as part of society life, have existed since long time ago. A gossip is defined as information which can't be confirmed, local character, new or important, and planned to be trusted [1], [2], [3], [4]. A Gossip —often treated as a rumor - according to Wert \& Salovey [5], tends to have its own-inner circle, so generally the gossip only circulates among people who have the same background or interest.

Investors are groups of individuals who own the same history and interest ${ }^{1}$, hence the term

${ }^{1}$ Kimmel [6] called as financial community gossip is more precise to be used in discussion about finance and investments. That is why Wysocki [7] ${ }^{2}$ used the term of cyber gossip to mention a rumor propagated in the internet by using various posting vehicles ${ }^{3}$. This research uses mailing list as vehicle to spread-up the gossips.

The role of gossips in stock investment actually is not new [8]. Investing in stock based on gossips, however, isn't a desired tradition [9]. Ideally, that activity is based on companies' financial fundamentals. Rose [10] and Rose et. al

\footnotetext{
${ }^{2}$ The first researcher who predict the impact of gossips that spread up through social media to stock value

${ }^{3}$ Such as mailing list, message board, facebook, Whats app, and others
} 
[11], however, found a fact that most investors don't understand and don't have capability to analyze a company's financial reports. Epstein and Pava [12], for instance, stated that almost 30\% of investors in the US are lack of knowledge that is necessary to understand the basic of a company's financial reports. Hawkins and Hawkins [13] also reported that more than $50 \%$ of US investors only read a company's annual report at a glance without analyzing it. As a substitute, investors use gossips as a basis when they make investment decision.

More and more investors have increased the usage of gossips in posting vehicle for getting information through social media [14]. Investors, for example, are able to download newsgroups, browse websites, set a blog, subscribe mailing lists, join the message boards, join the Facebook, joint Whats app, and other posting facilities. It is proven that the amount of gossips posted by investors in various posting media has increased year by year [15].

The problem is that gossips in social media are perceived negatively [16]. Even Dewally [17] firmly stated that he did not find facts that a recommendation taken from postings in social media has any value. There are some investors, however, who take benefit from the existence of gossip in social media [18], at least as early warning as happened in Enron scandal [19]. This situation may explain why investing by online has reduced the investors ability to make profit [20], but this doesn't degrade the migration of investment way from offline (conventional) to online.

Actually there were quite a lot researches that observed the relationship between sentiment ${ }^{4}$ and stock return that gave positive result [21], [22], [23]. Therefore, researches on stock values determination using gossip in social media still claim some yield. This research renews the previous one with new data. The rest of this article will consist of research methodology, result and discussion, and conclusion.

\section{Research Methodology}

Fisher \& Statman [21] found that sentiment ${ }^{5}$ from individual dan institutional investors could be used to determine stock return. Wysocki [7] concluded that posting volume could be used to determine stock return. Tumarkin \&Whitelaw [24], however, didn't find evidence that sentiment could work as determination on stock return, nor did Das \& Chen [25] and Antweiler \& Frank [15]. Antweiler \& Frank [26] found that there was a negative correlation between posting and stock return, but for determination they found that posting had negative influence and was significant to stock return although the coefficient value was too small (-.002). Otherwise, positive posting had positive impact and significance to influence stock return.

Das et al. [18] found that posting volume had a negative correlation with stock return on the same day, but had a positive correlation on the previous day. Dewally [17] detected that positiverecommendation follows good performance stocks, either in good or in bad market condition. In relation with momentum hypothesis, bad performance stocks precedes negative recommendation but is not significant. Furthermore, consistent to the no-value hypothesis, negative recommendation was followed by mixed (positive and negative) cumulative abnormal return (CAR), but was not significant although it was significant in the $1^{\text {st }}$ day to $20^{\text {th }}$ day during the bad market condition.

Based on those findings above, four hypotheses can be developed:

$\mathrm{H}_{1}$ : Buy posting from $\mathrm{t}_{-5}$ to $\mathrm{t}_{+5}$ can be used to determine stock return in bullish market condition

$\mathrm{H}_{2}$ : Exchange days have impact to stock return in bullish market condition

$\mathrm{H}_{3}$ : Sell posting from $t_{-5}$ to $t_{+5}$ can be used to determine stock return in bearish market condition

$\mathrm{H}_{4}$ : Exchange days have impact to stock return in bearish market condition

${ }^{5}$ Das et al [18] formulate sentiment as buy posting minus sell posting 
This research uses two kinds of data, namely primary and secondary data. Primary data consists of buy and sell posting volume. This data was collected from Junior Trader@yahoogroups.com mailing list. Data began March $1^{\text {st }}, 2017$ to June $30^{\text {th }}, 2017$ (representing the bullish market condition) and March $1^{\text {st }}, 2018$ to June $30^{\text {th }}, 2018$ (representing the bearish market condition).

Secondary data consists of daily stock prices that were collected from Yahoo! Finance. The data period is similar as the posting data period, starting from March $1^{\text {st }}, 2017$ to June $30^{\text {th }}, 2017$ and March $1^{\text {st }}, 2018$ to June $30^{\text {th }}, 2018$.

The posting data are sorted into four categories: buy, sell, neutral and others. Most previous researches used this category for sorting the posting data [18], [25], [21], [22] [23], but there is a difference among the researches to determine which posting is categorized as buy, sell, or neutral. Most of them, however, use algorithm and are supported by special software. Even the usage of a software will ease the sorting, but consensus technique is the most accurate.

This research uses consensus technique to determine the posting category. A posting will be categorized as buy when the posting sentence contains words such as buy; bullish; the tone of the sentence is optimistic; positive statement sentence; good news; own stock statement; negative response to sell posting. The consensus involves three people consisting of capital market practitioner, post-graduate student, and undergraduate student.

The population of this research is all stocks listed in the Indonesia Stock Exchange (IDX). All stocks, however, don't get postings. From the stocks that get postings also don't yield the amount of posting required. This phenomenon works as found by Wysocki [7], [28] that actually not too many investors upload their postings. Postings are also concentrated in five companies (Apple Computer, Intel, Oracle, Starbucks and MCI Worldcom). Therefore in relation with significance, this research used samples as its basis.

The sampling method applied here is purposive sampling with criteria: stocks that get the most buy posting in bullish market condition and sell posting in bearish market condition are included in the sample (this criteria follow Wysocki [7]. There are 20 stocks which get the most buy posting in bullish market condition, and also 20 stocks which get the most sell posting in bearish market condition.

Table 1 contains variable names, operational variable definitions and measurements that are used in this research. The main variable that is used for hypothesis testing is gossip in social media (buy and sell posting) and stock values (abnormal return).

Table 1.Variable Definition and Measurement

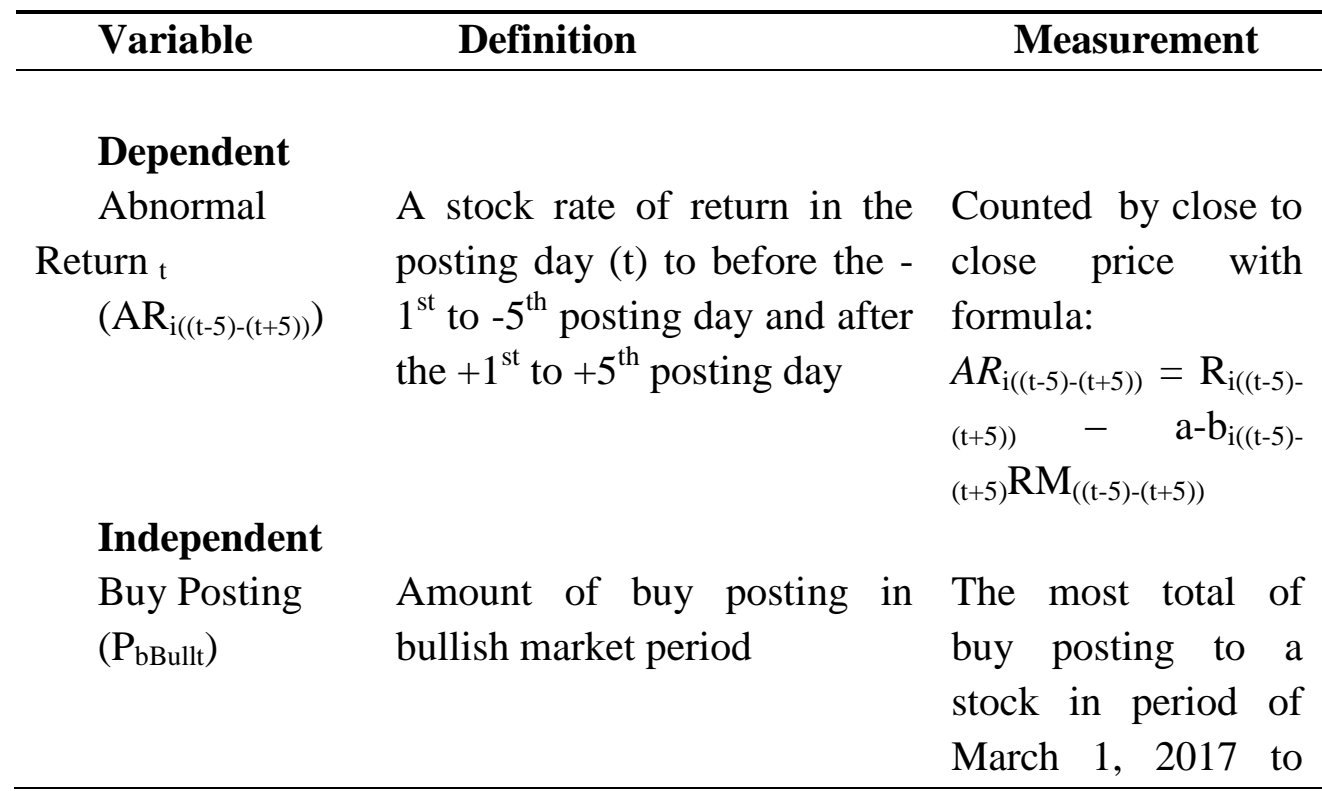


June 30, 2017

Sell Posting Amount of sell posting in The most total of $\left(\mathrm{P}_{\mathrm{jBeart}}\right)$ bearish market period sell posting to a stock in period of March 1, 2018 to June 30, 2018

\section{Control}

Monday

Tuesday

Posting on Tuesday

Totalpostingreceived by a stock on Tuesday, during 1 March 2017 to 30 June 2017 for bullish market period and 1 March 2018 to 30 June 2018 for bearish market period

Wednesday Posting on Wednesday

Totalpostingreceived by a stock on Wednesday, during 1 March 2017 to 30 June 2017 for bullish market period and 1 March 2018 to 30 June 2018 for bearish market period

Thursday Posting on Thursday Totalpostingreceived by a stock on Thursday, during 1 


\begin{tabular}{|c|c|c|}
\hline & & $\begin{array}{lll}\text { March } & 2017 \text { to } 30 \\
\text { June } & 2017 & \text { for } \\
\text { bullish } & & \\
\text { market } & \text { period and } 1 \\
\text { March } & 2018 \text { to } 30 \\
\text { June } 2018 \text { for } \\
\text { bearish } & \text { market } \\
\text { period } & & \end{array}$ \\
\hline Friday & Posting on Friday & $\begin{array}{l}\text { Totalpostingreceived } \\
\text { by a stock on Friday, } \\
\text { during } 1 \text { March } \\
2017 \text { to } 30 \text { June } \\
2017 \text { for bullish } \\
\text { market period and } 1 \\
\text { March } 2018 \text { to } 30 \\
\text { June } 2018 \text { for } \\
\text { bearish } \\
\text { period market }\end{array}$ \\
\hline
\end{tabular}

This research uses multivariate as analysis method to search the effect from each variable. Here are the models that will be regressed:

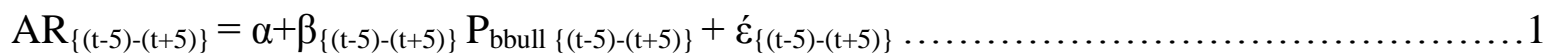

$\mathrm{AR}_{(\mathrm{t})}=\alpha+\beta_{1} \mathrm{P}_{\text {bbull }(\mathrm{t})}+\beta_{2}$ Monday $_{(\mathrm{t})}+\beta_{3}$ Tuesday $_{(\mathrm{t})}+\beta_{4}$ Wednesday $_{(\mathrm{t})}+\beta_{5}$ Thursday $_{(\mathrm{t})}$

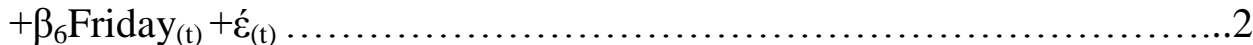

$\mathrm{AR}_{\{(\mathrm{t}-5)-(\mathrm{t}+5)\}}=\alpha+\beta_{\{(\mathrm{t}-5)-(\mathrm{t}+5)\}} \mathrm{P}_{\text {sbear }\{(\mathrm{t}-5)-(\mathrm{t}+5)\}}+\dot{\varepsilon}_{\{(\mathrm{t}-5)-(\mathrm{t}+5)\} \ldots \ldots \ldots \ldots \ldots \ldots \ldots \ldots \ldots \ldots \ldots \ldots \ldots \ldots \ldots \ldots \ldots \ldots \ldots \ldots \ldots \ldots \ldots \ldots \ldots \ldots \ldots \ldots}$

$\operatorname{AR}_{(t)}=\alpha+\beta_{1} P_{\text {sbear }(t)}+\beta_{2}$ Monday $_{(t)}+\beta_{3}$ Tuesday $_{(t)}+\beta_{4}$ Wednesday $_{(\mathrm{t})}+\beta_{5}$ Thursday $_{(\mathrm{t})}+\beta_{6}$ Friday $_{(\mathrm{t})}$

$+\dot{\varepsilon}_{(\mathrm{t})}$ 4

Variable $\mathbf{A R}_{\mathbf{t}}$ is calculated by using Atkins \& Dyl [29] formula:

$\mathrm{AR}_{\mathrm{it}}=\mathrm{R}_{\mathrm{it}}-\mathrm{a}_{\mathrm{i}}-\mathrm{b}_{\mathrm{i}} \mathrm{R}_{\mathrm{Mt}}$

Where:

$\mathrm{AR}_{\mathrm{it}} \quad$ : Abnormal return of stock $\mathrm{i}$ at period $\mathrm{t}$

$\mathrm{R}_{\mathrm{it}}$ : Return of stock $\mathrm{i}$ at period $\mathrm{t}$ (close to close)

$a_{i}$ : intercept of market adjusted return searched by formula, $R_{i t}=R_{i t}+a_{i}+B_{i r m t}+\dot{\varepsilon}_{i t}$

$\mathrm{R}_{\mathrm{Mt}}$ : Return market at period $\mathrm{t}$ (Composite Index of IDX), close-to-close

Variable $\mathrm{AR}_{((t-5)-(t+5))}$ explains abnormal return of event day $t$, where $t$ are posting days that was done five days before and after posting day $\mathrm{t}$, and $\mathrm{t}$ day. Variable $\mathrm{P}_{\text {bbullt }}$ represents amount of buy posting at market bullish condition in period $t$. Variable $\mathrm{P}_{\text {sbeart }}$ represents amount sell posting at market bearish condition in period t. Monday to Friday are exchange days.

\section{Result and Discussion}

In general, postings have effect on abnormal return as expected, but are not consistent. The effects are not only positive, but also negative and not only in previous posting days $\left(\mathrm{t}_{-1-}-5\right)$, but also in after posting days $\left(t_{+1-}+5\right)$. Besides the inconsistency, the most effect of posting on stock return is not significant in both bullish and bearish market conditions (see Table 2 and Table 4).

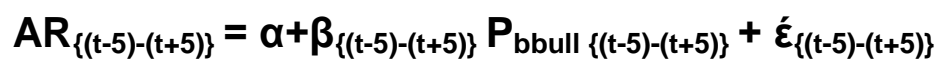


Table 2.Regression of Model

\begin{tabular}{cclclc}
\hline $\mathbf{A R}$ & $\boldsymbol{\alpha}$ & \multicolumn{1}{c}{$\boldsymbol{\rho}$} & $\boldsymbol{\beta}$ & \multicolumn{1}{c}{$\boldsymbol{\rho}$} & $\mathbf{R}^{2}$ \\
\hline $\mathrm{t}-5$ & 0.008 & $0.037^{* *}$ & 0.028 & 0.435 & 0.019 \\
$\mathrm{t}-4$ & 0.005 & $0.004 * * *$ & -0.019 & 0.286 & 0.023 \\
& & & & $0.002^{* *}$ & \\
$\mathrm{t}-3$ & 0.009 & 0.375 & 0.057 & $*$ & 0.045 \\
$\mathrm{t}-2$ & 0.002 & 0.245 & 0.045 & $0.025^{* *}$ & 0.135 \\
$\mathrm{t}-1$ & 0.006 & $0.001 * * *$ & -0.032 & 0.216 & 0.124 \\
$\mathrm{t}$ & -0.002 & 0.546 & 0.022 & 0.101 & 0.089 \\
$\mathrm{t}+1$ & 0.003 & $0.003^{* * *}$ & -0.033 & 0.175 & 0.095 \\
$\mathrm{t}+2$ & 0.009 & $0.065^{* *}$ & 0.016 & 0.568 & 0.034 \\
$\mathrm{t}+3$ & 0.004 & $0.004 * * *$ & -0.015 & 0.146 & 0.024 \\
$\mathrm{t}+4$ & 0.007 & $0.058^{*}$ & 0.013 & 0.544 & 0.023 \\
$\mathrm{t}+5$ & 0.003 & $0.016^{* *}$ & -0.012 & 0.698 & 0.045 \\
\hline
\end{tabular}

$* * *$ Significant at $\alpha 0.01$

$* *$ Significant at $\alpha 0.05$

* Significant at $\alpha 0.1$

The positive effect of buy postings on abnormal return only happened on day $\mathrm{t}-2, \mathrm{t}-3, \mathrm{t}-5$, $t+2$ and $t+4$ for bullish market condition. From all of those positive impacts, only posting on day $\mathrm{t}-2$ and $\mathrm{t}-3$ have significant impact. Posting on day $t$ actually has positive impact to stock return, but its significant value is 0.101 , or in other words, not significant. In statistical term, it is usually called as marginal (almost significant under $\alpha=0.1$ ). If the degree of significance $(\alpha)$ can be increased to more than $10 \%$, which is common in social science, the impact of posting on day to stock return will be positive and significant. Thus, the hypothesis that buy posting has positive impact to stock return can be proven and the conclusion that gossips in social media can be used as future stock return prediction can be received.

The persistence impact of gossip to the future stock return in bullish market condition tends to increase from posting on day to t $\mathrm{t}-3$, and then decrease on day $\mathrm{t}-4$ and increase again on $\mathrm{t}-5$. Otherwise in post posting day periods, this persistence tends to decrease. Based on this result, we can conclude that the persistence impact of gossip on future stock return is not too long.

Under bearish market condition, only on day $\mathrm{t}+2$ the sell posting has positive impact and

significant $(\rho=0.052)$. Posting on day $t$ has significant impact, unfortunately its coefficient is negative, and thus the result is inconclusive. The same as in bullish market condition, the persistence impact of gossip in social media to stock return in bearish market condition tends to decrease in post-posting period and will increase in pre-posting period.

In general, the results of regression model 1 and 3 are not significant, therefore hypothesis 1 $\left(\mathrm{H}_{1}\right)$ and hypothesis $3\left(\mathrm{H}_{3}\right)$ are not supported.

Because the impacts of gossip in social media on stock return mostly aren't significant, the coefficient determinations $\left(\mathrm{R}^{2}\right)$ are too low. The highest $\mathrm{R}^{2}$ in bullish market condition is $13.5 \%$ that happened on regression $\mathrm{t}-2$. It can be interpreted that only $13.5 \%$ of abnormal return can be explained by the variables in the models, and the rest can be explained by other factors. In bearish market condition, the highest $\mathrm{R}^{2}$ occurred on regression of day $t$, namely $11.2 \%$. This figure is slightly below the highest $\mathrm{R}^{2}$ in bullish market condition.

This kind of results are not surprising. Because previous studies also did not provide the same results. On the one hand, quite a lot of research results have shown a significant influence 
of gossip on stock returns, as have shown by Fisher \& Statman [21] and Wysocki [7]. Conversely, not a few researchers also did not find any significant influence between the gossip on stock returns. Some researchers who gave results like this include Tumarkin \& Whitelaw [24], Das \& Chen [25], and Antweiler \& Frank [15]. Even Antweiler \& Frank [26] found that there was a negative correlation between posting and stock return.
Those different results are obtained when research does not distinguish between bullish and bearish market conditions. However, when market conditions are differentiated, the results remain the same: gossip has no significant effect on stock returns. That is, market conditions are not important in explaining the influence of gossip on stock returns. Thus it can be said these results support the findings of Tumarkin and Whitelaw [24], Das \& Chen [25], and Antweiler \& Frank [15], and others.

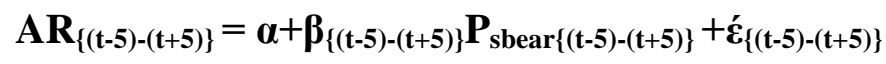

Table 3. Regression of Model 3

\begin{tabular}{cccrlr}
\hline $\mathbf{A R}$ & \multicolumn{1}{c}{$\boldsymbol{\alpha}$} & $\boldsymbol{\rho}$ & $\boldsymbol{\beta}$ & \multicolumn{1}{c}{$\boldsymbol{\rho}$} & $\mathbf{R}^{2}$ \\
\hline $\mathrm{t}-5$ & -0.004 & 0.213 & 0.045 & 0.321 & 0.017 \\
$\mathrm{t}-4$ & 0.002 & 0.721 & -0.032 & 0.434 & 0.014 \\
$\mathrm{t}-3$ & -0.001 & 0.654 & 0.021 & 0.721 & 0.012 \\
$\mathrm{t}-2$ & -0.0011 & 0.875 & -0.017 & 0.978 & 0.010 \\
$\mathrm{t}-1$ & -0.0006 & 0.653 & -0.002 & 0.966 & 0.00019 \\
$\mathrm{t}$ & 0.003 & 0.765 & -0.067 & $0.017 *$ & 0.112 \\
$\mathrm{t}+1$ & -0.0014 & 0.736 & 0.014 & 0.911 & 0.0012 \\
$\mathrm{t}+2$ & -0.005 & 0.342 & 0.035 & $0.052 *$ & 0.052 \\
$\mathrm{t}+3$ & 0.0003 & 0.896 & 0.003 & 0.875 & 0.0013 \\
$\mathrm{t}+4$ & 0.0002 & 0.945 & 0.02 & 0.7720 & 0.005 \\
$\mathrm{t}+5$ & 0.003 & 0.867 & 0.011 & 0.652 & 0.002 \\
\hline *** Significant at $\alpha 0.01$ & & & & \\
** Significant at $\alpha 0.05$ & & & & \\
* Significant at $\alpha 0.1$ & & & &
\end{tabular}

Models 2 and 4 are used to test the impact of posts on post day (t) and exchange day. In bullish market conditions, posting on $t$-day has a positive and significant effect on stock returns on the same day. The significance value on day $t$ is 0.08 (see table 3). There is no significant effect of exchange day on stock returns. This shows that the post really affects the stock return. At least on day t. Abnormal returns are caused by gossip in social media, and not by exchange day. Thus Hypothesis 2 is not accepted.

$\mathrm{AR}_{(\mathrm{t})}=\alpha+\beta_{1} \mathrm{P}_{\text {bbull }(\mathrm{t})}+\beta_{2}$ Monday $_{(\mathrm{t})}+\beta_{3}$ Tuesday $_{(\mathrm{t})}$ $+\beta_{4}$ Wednesday $_{(\mathrm{t})}+\beta_{5}$ Thursday $_{(\mathrm{t})}+\beta_{6}$ Friday $_{(\mathrm{t})}+\dot{\varepsilon}_{(\mathrm{t})}$
Table 4. Regression of Model

\begin{tabular}{|c|c|c|}
\hline Variable & $\beta$ & $\rho$ \\
\hline Constant & -0.02 & 0.72 \\
\hline $\mathrm{P}_{\text {bbull }}$ & 0.27 & $0.08 *$ \\
\hline Monday & 0.33 & 0.65 \\
\hline Tuesday & 0.29 & 0.45 \\
\hline Wednesday & 0.25 & 0.76 \\
\hline Thursday & 0.19 & 0.74 \\
\hline Friday & 0.20 & 0.85 \\
\hline $\mathrm{R}^{2}$ & 0.15 & \\
\hline
\end{tabular}


In bearish market conditions, there is no significant effect of posting day on stock returns. Also none of the exchange days has a significant effect on stock returns. Thus, for bearish market conditions, both posting day and exchange day do not have a significant effect (see table 5). Thus the same as in bullish market conditions, Hypothesis 4 can't be accepted.

The results that indicate that buying post has a positive and significant effect on stock returns in bullish market conditions again shows support for the results of previous studies, as did by Fisher \& Statman [21] and Wysocki [7]. While the results that show the insignificant influence of gossip on stock returns on bearish market conditions, provide support for the results of previous studies such as those conducted by Tumarkin \& Whitelaw [24], Das \& Chen [25], and Antweiler \& Frank [15].

Furthermore, there is no significant effect of posting on certain exchange days on stock returns actually related to previous research on anomalies that occur on the stock exchange, especially the week end effect, also known as the Monday effect.

As is known the Monday effect is a theory which states that returns on the stock market on Mondays will follow the prevailing trend from the previous Friday. Therefore, if the market was up on Friday, it should continue through the weekend and, come Monday, resume its rise. Research on weekend anomaly effects has been done, and the results show the existence of these anomalies. Continuing this logic, the posting on Friday should have an effect on stock returns. However, this influence did not occur for both bullish and bearish market conditions. This kind of results can be understood into two parts, the first part is that posting on a certain day does not have an impact on stock returns on the Indonesian stock exchange. The second part, the week end effect anomaly does not occur in the Indonesia stock exchange.

$$
\mathrm{AR}_{(\mathrm{t})}=\alpha+\beta_{1} \mathrm{P}_{\text {sbear }(\mathrm{t})}+\beta_{2} \text { Monday }_{(\mathrm{t})}+\beta_{3} \text { Tuesday }_{(\mathrm{t})}+\beta_{4} \text { Wednesday }_{(\mathrm{t})}+\beta_{5} \text { Thursday }_{(\mathrm{t})}+\beta_{6} \text { Friday }_{(\mathrm{t})}+\dot{\varepsilon}_{(\mathrm{t})}
$$

Table 5.Regression of Model 4

\begin{tabular}{lcc}
\hline Variable & $\boldsymbol{\beta}$ & $\boldsymbol{\rho}$ \\
\hline Constant & -0.019 & 0.43 \\
$\mathrm{P}_{\text {sbear }}$ & 0.089 & 0.41 \\
Monday & 0.46 & 0.32 \\
Tuesday & 0.32 & 0.65 \\
Wednesday & 0.20 & 0.69 \\
Thursday & 0.23 & 0.23 \\
Friday & 0.35 & 0.67 \\
$\mathrm{R}^{2}$ & 0.054 & \\
\hline \multicolumn{3}{c}{$* * *$ Significant at $\alpha 0.01$} \\
\multicolumn{2}{c}{$*$ Significant at $\alpha 0.05$}
\end{tabular}

From the using of gossip in social media regression models (buy and sell posting), we found that they don't show the existence of significant impacts of the gossip in social media on stock values. This isn't a surprise. This result means that it will complement the previous studies that predicting the information collected from discussions on the internet doesn't have any meaning to investment decision making (see, for example, Das \& Chen, 2001 and Das et al., 2005). Antwiler \& Frank (2004) called it as "all that talk just noise".

When we watch the significant impact of buy postings on abnormal returns that is near the level of confidence $10 \%$ (pricely $0.111 \%$ on the $t$ exchange day), however, actually there is a room to support hypothesis 1. Even if we lower the level of confidence to $15 \%$, we can support hypothesis 1. In other words, gossip in social media can be used to determine the stock returns in bullish market period.

On the contrary, investors in the Indonesia Stock Exchange are almost impossible to use the gossip in social media as determination parameters for determining stock returns in a bearish market period. This finding is shown by 
the most insignificant impacts of the sell postings on abnormal returns in all $t$ days.

With this finding, it is clear that it is impossible for the Indonesia Stock Exchange investors to use information from the internet to reap gain by posting the information to the internet before making investment decisions (buying or selling stocks).

It is precisely the possibility of what were found by previous researchers (as Tumarkin and Whitelaw, 2001; Das \& Chen, 2001; Antweiler \& Frank, 2002; 2004) that there wasn't any evidence that sentiments ${ }^{6}$ could be used to determine the stock returns. Even Das et al. (2005) concluded that investors didn't post first then invested, on the contrary investors watched stock values performance first before they invested.

\section{Conclusion}

This research proposes a problem whether the gossip in social media can be used to determine stock returns. From the results of hypothesis tests using the models, factually the buy and sell postings coefficient values are found insignificant, except for the t-2 and t-3 day in bullish market condition and $\mathrm{t}+2$ day in bearish market condition. Thus, the answer to the research problem is that gossips in social media can't be used to determine stock returns.

This conclusion for sure is only valid for this research, which is limited by bullish and bearish data as determined before. Moreover, it is also based on stock investment in the Indonesia Stock Exchange context, where the phase of using gossips in social media is still limited.

In the meantime, the persistence impact of gossip in social media on stock returns isn't too long. During five exchange days after posting, the impact is seen to decline. While, for pre-posting period, the impact of gossip in social media on the stock returns is seen to rise.

Last but not least, there is an interesting thing that must be noted. When posting day regress together with exchange day, posting day has positive and significant impact on stock return in the same day. On the contrary, there is no one of exchange days has significant impact on stock returns. This result shows that, gossips in social media can still be used to determine stock returns or gossip is more important than exchange day to influence stock return.

\section{References}

[1] Rosnow, R. L.: Rumor as Communication: A Contextualist Approach. Journal of Communication, Vol. 38, No. 1, pp. 12-28 (1988)

[2] Rosnow, R. L.: Inside rumor: A Personal Journey. American Psychologist, Vol. 46, No. 5, pp. 484-496 (1991)

[3] Rosnow, R. L.: Rumor and Gossip in Interpersonal Interaction and Beyond: A Social Exchange Perspective. In R. M. Kowalski (Ed.), Behaving Badly: Aversive Behaviors in Interpersonal Relationships. Washington, DC: American Psychological Association (2001)

[4] DiFonzo, N., and P. Bordia (1997). Rumor and prediction: Making Sense (But Losing Dollars) in The Stock Market. Organizational Behavior and Human Decision Processes, Vo. 71, No. 3, pp. 329-353 (1997)

[5] Wert, Sarah, R., \& Peter S.: Introduction To the Special Issue on Gossip. Review of General Psychology, Vol. 8, pp.76-77 (2004)

[6] Kimmel, A. J.: Rumors and the Financial Market Place. The Journal of Behavioral Finance, Vol. 5, No. 3, pp. 134-141(2004).

[7] Wysocki, Peter, D.: Cheap Talk on The Web: The Determinants of Posting on Internet Stock Message Boards. Working Paper. University of Michigan Business School. November(1998)

[8] Leinweber, DavidJ.,Ananth N. M.: Three Hundred Years of Stock Market Manipulations. Journal of Investing, Vol. 10, No. 2, pp. 7-16 (2001) 
[9] Jones, Charles, P.: Investment, Analysis and Management. New Jersey: John Weley \& Sons (2004)

[10] Rose, Jacob M.: The Effects of Multimedia-Induced Affective States on Recall and Decision-Making By Individual Investors. International Journal of Accounting Information Systems, Vol. 2, pp. 22-40 (2001)

[11] Rose, Jacob M., F. D. Roberts, and A. M. Rose: Affective Responses to Financial Data and Multimedia: The Effects of Information Load and Cognitive Load. International Journal of Accounting Information Systems, Vol. 5, pp. 5-24. (2004)

[12] Epstein, Marc J., dan Moses L. Pava: Individual Investor's Perceptions on the Summary Annual Report: A Survey Approach. Journal of Applied Business Research, Vol.10, No. 3, pp. 60-67 (1994)

[13] Hawkins, D., and B. Hawkins: The Effectiveness of the Annual Report as a Communication Vehicle. Morristown, NJ: Financial Executives Research Foundation (1986)

[14] Hodge, F., and M. Pronk: The Impact of Expertise and Investment Familiarity on Investors' Use of Online Financial Report Information. Working paper, University of Washington, Vol. 38 (2006)

[15] Antweiler, Werner dan Murray Z. Frank: (2002). Internet Stock Message Boards and Stock Return. Working Paper. University of British Columbia (2002)

[16] Crawford, Alan P.: When Those Nasty Rumors Start Breeding on the Web, You've got to Move Fast. Public Relations Quarterly, Vol. 44, No. 4, pp. 43-45 (1999)

[17] Dewally, M.: Internet Investment Advice: Investing with a Rock of Salt. Financial Analysts Journal, Vol. 59, No. 4, pp. 65-83 (2003)

[18] Das, S.R., Asis M. J. \& Peter T.: eInformation: Clinical Study of Investor Discussion and Sentiment. Financial
Management, Vol.34, No. 3, pp. 103-107 (2005)

[19] Felton, J. and Jongchai K.: Warnings From the Enron Message Board. Journal of Investing, Vol.11, No. 2, pp. 29-53 (2002)

[20] Barber, B. M. and Terrance O.: Trading Is Hazardous to Your Wealth: The Common Stock Investment Performance of Individual Investors. Journal of Finance, Vol. 55, No. 2, pp. 773-806 (2000).

[21] Fisher, K. L. and Meir S.: Investor Sentimen and Stock Returns. Financial Analysts Journal, Vol. 56, No. 2, pp. 16-23 (2000)

[22] Fisher, Kenneth, L. and Meir S.: Sentimen Value and Market Timing. Journal of Investing, Vol. 13, No. 3, pp. 10- 21 (2004).

[23] Sehgal, V. and Charles S.: SOPS: Stock Prediction Using Web Sentiment. Proceedings of the Seventh IEEE International Conference on Data Mining Workshops. IEEE Computer Society(2007)

[24] Tumarkin, Robert \& Robert. F. Whitelaw. (2001). News or Noise? Internet Message Board Activity and Stock Prices. Financial Analysts Journal, Vol. 57, No. 3, pp. 41-51 (2001)

[25] Das, S. R. and Mike. Y. C.: Yahoo! for Amazon: Sentiment Parsing from Small Talk on the Web. Working Paper. Santa Clara University(2001)

[26] Antweiler, W. and Murray Z. F.: Does Talk Matter? Evidence From A Broad Cross Section of Stocks. Working paper. University of British Columbia (2004)

[27] Lewis, D. D.: Naïve (Bayes) at Forty: The Independen Assumtion in Information Retrievel. Proceeding of $10^{\text {th }}$ European Conference on Machine learning (ECML). Springer Verlag, New York (1998)

[28] Wysocki, Peter, D.: Short Seller and Message Posting Activity on the Web. Working Paper, University of Michigan Business School. October (1999) 
[29] Atkins, A. B. and Edward A. D.: Price Reversals, Bid-Ask Spreads, and Market Efficiency. Journal of Financial and Quantitative Analysis, Vol. 25, No. 4, pp. 535-547 (1990) 